\title{
Determinants of National Saving In Saudi Arabia*
}

\section{Dr. Mahmoud Abdelaziz Touny}

Assistant Professor of Economics

Faculty of Commerce \& Business

Administration - Helwan University

Associate Professor - Faculty of Applied Studies

and Community Services, Dammam University

\section{Prof. Jameel Ahmed Khder}

Professor of Marketing

Department of Administrative Sciences

Marketing Program

Riyadh Community College

King Saud University, KSA

\begin{abstract}
:
This paper has analyzed the determinants of national savings in Saudi Arabia during the period 1980-2010. The ADF test is used to investigate the stationary of all time series, and after that, we estimated unrestricted VAR model. The results of the estimated VAR model provide evidence that the growth rate of per capita income, population growth, and financial depths have positive influence on national savings in Saudi Arabia during the period study. On the other hand, macroeconomic uncertainty, as measured by the inflation indicates a negative but insignificant effect on national saving rate. Foreign reserves ratio appears to have a negative effect on national savings, which implies that foreign saving may tend to act as a substitute to national savings. Moreover, the results of our study confirm that budget deficit ratio has a negative and statistically significant effect on the national saving ratio, which does not support the Ricardian hypothesis due to the limited use of taxes as a tool of fiscal policy in Saudi Arabia. This result suggests that government should use fiscal policy to reduce budget deficit, and restructure government expenditure in the way that can boost private savings and thus offset the negative effect on national savings.
\end{abstract}

\section{I- Introduction}

Saving is primarily used to finance investments. Much of disparity in the growth performance between countries is often attributed to the differences in the rates of saving and investment. Low domestic saving rates may maintain low-growth levels. When domestic resources are not enough to finance investment requirements, external sources are allowed to fill in this gap. While depending on foreign savings has its own benefits, it makes the country highly sensitive to external shocks. Therefore, domestic savings will continue to be a priority as a source of investment financing in order to minimize vulnerability to international economic fluctuations. In recent years, there has been a great interest of empirical works on the determinants of saving in both developed and developing countries. This attitude has been motivated by the widespread concern over falling saving rates in the major OECD countries and the growing divergence in saving and investment rates between countries of the developing world (Athukorala and Sen, 2004).

With regard to Saudi Arabia, investment behavior witnessed relatively low records, with an average of gross fixed capital formulation as a ratio of GDP to be 20.54 percent through

* The Authors Extend Their Appreciation to the Deanship of Scientific Research at King Saud University for Funding the Work Through the Research Group Project No. RGP-VPP-076.

* This Research Was Submitted in Oct. 2012, and Accepted for Publishing in Dec. 2012. 
the period $2000-2010$, whereas the ratio of national savings to GDP, on average, recorded 42.43 percent during the same period ${ }^{(1)}$. There is no doubt that an understanding of the fundamental determinants of saving in Saudi Arabia represents an importance issue in order to formulate policies to maintain and increase the domestic saving behavior and formulate adequate policies to make use of these savings to increase investment levels. In this paper, we investigate some macroeconomic factors as possible explanations for national savings behavior in Saudi Arabia.

Thus, the research points of this paper can be summarized in the following questions:

- Does income growth have a positive effect on national savings?

- Is there a full crowded out effect of budget deficit to private savings? (The Ricardian hypothesis).

- Does financial market development have a positive effect on national savings?

- Do foreign savings represent a substitute or a complement of national savings?

- Does macroeconomic stability have an influence on national savings?

- Does population growth have a significant effect on national savings?

We use unit root test to examine the stationary of variables and apply the most proper model (unrestricted VAR model) for our variables to examine the determinants of national saving rates in Saudi Arabia through the period 1980 - 2010. These techniques are more powerful than the conventional tests and overcome the inconsistency problem of OLS estimator employed in some previous studies of saving behavior.

The paper is structured as follows. Section II discusses the theoretical and empirical literature concerning the determinants of savings. Section III, displays some stylized facts of saving behavior and the explanatory variables of national savings in Saudi Arabia during the study period. Based on the data, section IV explores the relationship between national savings and the explanatory variables included in the econometric model. Finally, section IIV provides a short conclusion and policy implications.

\section{II- Theoretical and Empirical Literature:}

Theoretical literature studying savings determinants reveals that there emerge two major hypotheses. The first one is the Permanent Income Hypothesis of Friedman (1957). This hypothesis differentiates permanent and transitory components of income as determinants of savings. The key conclusion of this theory is that transitory, temporary changes in income have little effect on consumer spending behavior, whereas permanent changes can have large effects on consumer spending behavior. Permanent income is defined in terms of the long time income expectation over a planning period and transitory income is the difference between the measured income and the permanent income. The second one is Modigliani's Life Cycle Hypothesis. According to this hypothesis, individuals plan their consumption and savings behaviour over the long term and intend to even out their consumption in the best possible manner over their entire lifetimes. Thus, consumption is evenly distributed over time and this, in turn, implies that the individual during his active period builds up a stock of wealth, which he consumes during his old age. The key assumption is that all individuals choose to maintain stable lifestyles. This implies that they usually don't save up a lot in one

(1) Calculated by the authors depending on data available from Saudi Arabian Monetary Agency, anual report (47), 2011. 
period to spend furiously in the next period, but keep their consumption levels approximately the same in every period (Özcan et al 2003; Jappelli 2005).

The life-cycle hypothesis proposed by Modigliani (1986) provides a theoretical framework of most determinants of saving behavior used in recent empirical studies. In this context, we try to analyze the theoretical framework of these determinants, followed by some recent empirical studies investigated these factors.

\section{Income Growth:}

The fundamental assumption of the life-cycle hypothesis is that an individual seeks to maximize the present value of lifetime utility subject to the budget constraint. The theory predicts that consumption in a particular period, and thus the decision to save, depends on expectations about lifetime income. According to this theory, the lifetime of an individual is divided into a working period and a retirement period. Individuals are assumed to be net savers during the working period and dissavers during the retirement period. In the light of that, growth of per capita income will result in an increase of aggregate saving rate, because it increases the lifetime earnings and saving of younger age groups relative to older age groups (Athukorala and Sen, 2004). Thus countries with higher per capita growth rates are expected to have higher saving ratios than countries with lower growth rates. However, there is another view indicates that the size of this effect is likely to decline as per capita income rises and may even become negative for rich countries where investment opportunities and growth are relatively lower (Masson et al, 1998).

\section{Demographic Factors:}

Demographic factors such as population age-structure and dependency ratio also affect saving performance. During childhood and old age, people on average consume more than they produce through their labor. During the middle years, people produce more than their consumption. The life cycle theory assumed that when there are too many young people to support, consumption increases and saving declines. The theory distinguished between dependency ratio and population growth on its effect on saving ratio. It indicated that although an increase of population growth rate may increase the number of active workers (savers) relative to the number of retired (dissavers), however, this may be accompanied by an increase of young ratio (dissavers) in the population as well. Thus the net effect of population growth on aggregate saving is theoretically unclear (Athukorala and Sen, 2004).

\section{Fiscal Policy:}

The neo-classical version of the lifecycle model assumes that a decline in government saving (more budget deficit) will tend to raise consumption and discourage saving by shifting the tax burden from present to future generations. As a result of that, a decline in government savings will cause a decline in national savings. There is another view indicates that an increase in government savings would have no effect on national savings, as it would be completely offset by a corresponding fall in private savings "The Ricardian Equivalence" (Özcan et al, 2003). According to the Ricardian Equivalence Hypothesis, it does not matter whether government finances its expenditure through taxes or by borrowing. The Ricardian Equivalence depends on the assumption of perfect capital markets, and therefore saving behaviour does not experience any uncertainty. However, if this assumption does not hold, then perfect substitution between public and private savings will not be achieved (Athukorala and Sen, 2004). 


\section{Interest Rate:}

The life-cycle theory introduced that the net effect of the real interest rate on savings is unclear. The net effect of the real interest rate on savings can be decomposed into two effects. The substitution effect implies that a higher interest rate increases the current price of consumption relative to the future price, and thus affecting savings positively. The other effect, which is called the income effect, indicates that if the household is a net lender, an increase in the interest rate will increase lifetime income, and so increase consumption and reduce saving. Therefore, it is expected that the interest rate will have a positive impact on saving ratio only when the substitution effect dominates the income effect. In developing countries where financial markets are still not well developed, substitution effect is expected to be much greater than income effect, and thus the real interest rate is likely to have a net positive impact on domestic savings (Özcan et al, 2003). However, the complexity and distortions in both the real and the financial sides of the economy tend to reduce the benefits of an increase in interest rates, and thus the positive impact on domestic savings may not be achieved.

\section{Inflation and Macroeconomic Uncertainty:}

The life cycle hypothesis implies that inflation is neutral because of the absence of money illusion, and thus inflation does not have a real effect on saving behavior. However, uncertainty in the form of inflation should rise saving since risk-averse consumers tend to set some resources aside as a precaution against possible adverse changes in future income (Loayza et al, 2000). In that case, individuals will limit their present consumption and save more in order to consume more in future. On the one hand, inflation could affect savings through real wealth. Inflation acts as a tax on money balance holdings, so if individuals wish to maintain the real value of their money balance holdings (the real balance effect), saving will rise with the rate of inflation (Hussein and Thirlwall, 1999).

\section{Financial Development:}

The degree of financial sector development and the range and availability of financial assets to suit savers represents another important factor in promoting savings. The expansion of bank branches and improving the accessibility to banking facilities will result in reducing the cost of banking transactions, and thus motivate individuals' savings. On the other hand, if financial institutions are not well organized and stable, savings will be kept in non-monetary terms such as jewelry and real estate, and this may defeat the main purpose of saving. Therefore, the potential positive effect between the development of the consumer's credit market and household financial saving depends also on the degree of substitution between financial saving and other forms of savings in the household asset portfolio. As a result of that, the potential impact of financial development on private savings seems to be ambiguous (Athukorala and Sen, 2004).

\section{External Variables:}

The external variables that might be relevant to savings are the current account deficit and terms of trade. It is suuposed that an increase in the current account deficit (foreign saving) is associated by a partial decline in private saving, as foreign saving may tend to act as a substitute to domestic saving (Özcan et al, 2003). When foreign reserves data is available, it is better to use it to reflect foreign savings.

Terms of trade represents another external variable that may have an effect on saving behavior especially for the oil exporters. Positive terms of trade may result in an increase of 
savings through the positive effect on wealth and income. The traditional explanation of this relationship is illustrated in the Harberger - Laursen - Metzler hypothesis. It assumes that deterioration in terms of trade reduces real income and thus saving. This hypothesis assumed myopic expectations of consumers. However, recent literature argues that a change in terms of trade has an ambiguous effect on saving depending on whether the change in the former is seen to be permanent or temporary. A transitory improvement in terms of trade causes only a transitory change in income, and thus should lead to higher saving rather than higher consumption. This conclusion supports the direction of the Harberger - Laursen - Metzler effect. Nevertheless, a permanent improvement tends to reduce saving as consumers increase their consumption. Thus, the effect of terms of trade changes on saving depends on whether the change was anticipated or not (Masson et al, 1998).

The empirical studies that examined these determinants in developed or developing countries took several ways. Some studies have concentrated mainly on fixed-effect models using OLS estimates to explain the variations in saving performance among countries. Other studies depended on some robust techniques such as co-integration and integration tests, which allow for heterogeneity in parameters and dynamics across countries, to examine the long-run determinants of saving rates.

Some of these studies concentrated mainly on interactions between demographic factors (i.e. Fertility rates, the dependency ratio, life expectancy) and saving. Others examined a variety of macroeconomic variables such as income, real interest rate, changes in terms of trade, money supply, government expenditure and openness of economy to capture the main determinants of saving levels. Add to that, other researchers used a mixed of demographic and macroeconomic factors. We cannot separate the previous studies into groups according to factors determining the saving performance as most of these studies gather more than one group of factors to include the most possible factors and reveal the true determinants of variations in saving ratios. Thus, we will display these studies chronologically.

In an attempt to investigate the determinants of saving rate in Pakistan, Khan et al (1994) used a variety of factors that included income, real interest rate, dependency ratio, foreign capital inflows, foreign aid, changes in terms of trade and openness of economy. The study found a strong and positive effect of per capita GNP on national saving. In addition, it was found that real interest rate, change in terms of trade and openness of the economy positively influenced national saving. On the other way, debt to GNP ratio and dependency ratio were found to have adverse impact on national saving.

Among several other empirical studies, Edwards (1996) by using panel data for 36 countries over the period 1970 to 1992, examined the process of determination of saving rates by incorporating some policy-related, demographic, structural and political variables that possibly determine the saving ratio. Per capita income growth seemed to be the most important determinant of private and public savings. Moreover, the results indicated that public savings were lower in countries with higher political instability, and public savings crowded out private savings, but less than proportionately.

Dayal-Ghulati and Thimann (1997) analyzed the empirical determinants of private savings for a sample of economies in Southeast Asia and Latin America over the period 19751995. The findings indicated that fiscal policy, particularly social security arrangements, may be the core policy instruments that boosted saving rates in some Asian countries. In addition, 
inflation volatility appeared to have a negative effect on the private saving rate in Latin America. The same is true for economic policies that liberalize financial markets and foster financial deepening. Macroeconomic stability and financial deepening were clearly important variables determining saving behavior in the two regions as well.

To identify the empirical determinants of household saving, Callen and Thimann (1997) analyzed the empirical determinants of household saving using data from 21 OECD countries for 1975-95. This study focused on the influence of tax and social security systems on household saving. The paper therefore extended the usual set of explanatory variables used to explain household saving behavior to include variables that capture the structure of the tax system and the financing of the social security and welfare system. These variables were found to have an important impact on household saving, and thus gave a signal to policy makers that by changing the design of these systems, governments may be able to influence saving.

Masson et al (1998) examined the determinants of private savings for a large sample of industrial and developing countries using both time series and cross-section data. The results suggested that there was a partial offset to private savings from changes in public saving for industrial countries, whereas in developing countries demographics and GDP growth were the most important determinants of private saving rates.

In another study, Cardenas and Escobar (1998) analyzed the determinants of saving in Colombia during the 1925-1994 period, using a framework of intertemporal model. The findings reinforced the importance linkage among national savings, government expenditure and age dependency. The results concluded that national saving partially responded to temporary changes in output, and higher government expenditures were associated with lower national saving. The results also indicated that an increase in age dependency has a significantly negative effect on private saving rates.

Al-Mohaimeed (2000) examined the factors influencing Saudi domestic saving using dynamic OLS and error-correction models for the period 1968-1996. The results from various models confirmed the significant role of income in determining domestic saving rate. Secondly, in contrast to what is often expected, increase in birth rate has positive effect on domestic saving in Saudi Arabia, which is consistent with the special characteristic of Saudi society. Also, the results demonstrated a crowding out of foreign capital inflow in the short run, and real exchange rates exhibited significant effect on domestic saving only in the long run. Moreover, the study illustrated that government saving, which account for a large proportion of gross domestic saving, has been significantly deteriorating in the last decade of the data, recommended that the government should adopt policies that improve saving position.

The extreme-bounds analysis was used by Hussain and Brookins (2001) to examine the determinants of national savings, based on both cross-sectional and panel data across a large sample of countries. Their results supported that agricultural share in total output, public saving, budget balance, and the current account balance were robust in explaining saving behavior.

Sarantis and Stewart (2001) used panel co-integration and integration tests to examine the long-run determinants of aggregate private saving rates in a dynamic panel of OECD countries during the post Second World War period. They found strong evidence for the existence of a long-run equilibrium saving function. Although the results suggested a number of significant determinants of saving rates, the parameter estimates varied significantly across countries. 
In Jordan, Hallaq (2003) analyzed and examined the determinants of private savings during the period 1976-2000 using the OLS and the instrumental variable methods. The main results indicated that the dependency ratio had a negative and significant effect on private savings, and government savings depressed private savings. However, GDP growth rate and GDP per capita income had a significant positive effect on private savings. Moreover, the development of Jordan consumer's credit market, the ratio of social security, and welfare public expenditures to total public expenditures appeared to have positive effects on private savings. Finally, the real interest rate, inflation rate, and terms of trade were found to have insignificant impact on the level of private saving in Jordan.

Özcan, et al. (2003) investigated the determinants of private saving for Turkey through the period 1968-1994 using a number of policy and no policy variables. The findings of the OLS estimated model supported the hypothesis that the private saving rates have strong inertia. It was found that the effects of a change in a given saving determinant were fully realized in the long term rather than in the short-term. The findings further indicated that although higher government savings crowded out private savings, they did it in less than one-to-one manner, and thus the Ricardian Equivalence did not hold strictly. In addition, income level showed a positive effect on the private saving rate, however, the growth rate of income was not statistically significant. Moreover, financial depth and development measure of Turkey suggested that countries with deeper financial systems tend to have higher private saving rates. The results also indicated that life expectancy rate tends to have a negative impact on savings. Furthermore, the precautionary motive for saving was supported by the findings that inflation captured the degree of macroeconomic uncertainty and had a positive impact on private saving in Turkey. With regard to external factors, it was found that terms of trade shocks increased private saving in Turkey. Although the current account deficit represents an important explanatory variable for the private savings, its effect was insignificant in Turkey.

In India, Athukorala and Sen (2004) examined the determinants of private saving during the period 1954 - 1998. The methodology used in this study involved the estimation of a saving rate function derived from the life-cycle model that has been the standard theory for the explanation of changes in private saving over time and across countries. The results of the estimated model provided an evidence of a statistically positive effect of the real interest rate, the growth and the level of per capita income, the spread of banking facilities, and the rate of inflation on domestic saving. On the other hand, terms of trade and inward remittances by expatriate Indians witnessed a negative impact on the saving rate. Fiscal policy reported that public saving seemed to be an imperfect substitute for private saving. The result relating to the inflation rate suggested that mild inflation seemed to have a positive impact on private saving.

In another study, the relationship between a variety of macroeconomic variables and private savings was broadly examined by Metin_Özcan and Özcan (2005) using a sample of 15 countries in the Middle East and North Africa (MENA) over the period 1981-1994. The estimated results provided further evidence of the significantly positive effect of the growth rate of income, and per capita income on private savings. In addition, public savings crowded out private savings only partially which means that the Ricardian Equivalence does not hold strictly. Regarding the financial factors, the paper provided evidence that countries with deeper financial systems tend to have higher private savings. Moreover, macroeconomic stability captured by the inflation rate was found to have a positive impact on savings. 
To explore the relative importance of national saving determinants in Oman, Narayan and AL Siyabi, S. (2005) examined the long run and short run effects of Oman's national savings for the period 1977-2003 using the bounds testing approach to co integration. The main findings provided strong evidence that the current account, the urbanization rate and the money supply had statistically significant impacts on Oman's national savings on the long run.

Odhiambo (2008) used a dynamic Granger causality test to examine the causal relationship between financial development, savings and economic growth in Kenya through the period $(1969$ - 2005). Using the cointegration and error-correction techniques, the empirical results of this study reveal that economic growth Granger causes savings, while savings drive the development of the financial sector in Kenya.

In another study, Odhiambo (2009) examined the direction of causality between savings and economic growth in South Africa during the period 1950-2005. Using the cointegrationbased error-correction mechanism, the study found a bi-directional causality between savings and economic growth to prevail in the short run and a distinct unidirectional causal flow from economic growth to savings to dominate in the long run. Therefore, the study concluded that, while in the short run both savings and economic growth drive each other, in the long run, it is the growth of the real sector which drives up the accumulation of savings. The results also show that foreign capital inflow and savings Granger-cause each other.

In USA, Kim (2010) using time series data of the U.S. through the period 1950 - 2007, investigated a number of internal and external variables that could affect personal saving. Empirical analysis shows that the personal saving rate is more sensitive to changes in internal variables such as personal income, tax, credit outstanding and status of employment, while dependency ratio, current real estate loan, real interest rate and status of economic performance are indeterminate.

To study the determinants of the annual household saving rate in the United States, Gough (2011) analyzed the quantitative relationship between several variables and a measure of the annual household saving rate. Gough used a sample of time-series data from 1964-2008 and concluded that household uncertainty, the percentage of the U.S. population that is college educated, the percentage of the U.S. population that is nonworking, the annual percentage change in real personal disposable income, and the real interest rate are all statistically significant in explaining changes in the saving rate. These results are consistent with the life cycle model and find a significant effect from precautionary motives for saving, however, they fail to find a significant wealth effect explaining changes in saving patterns.

Keho (2011) examined the long-run determinants of savings rates for seven member countries of the West African Economic and Monetary Union over the period 1970-2006. He used the bounds testing approach to cointegration, and found that the financial liberalization process undertaken at the end of 1989 and the existing monetary policy have not been effective to increase the domestic savings rates within the area.

Horioka and Terada-Hagiwara (2012) analyzed the determinants of domestic saving rates in twelve economies in Developing Asia during the 1966-2007 period through estimating both a country fixed effects model and a random effects model with robust standard errors. They also estimated trends in domestic saving rates in these same economies during the next twenty years 
(2011-2030 period) based on their estimation results. Although, their empirical results indicated that there have been substantial differences from economy to economy, the main determinants of these trends appear to have been the age structure of the population (especially the aged dependency ratio), income levels, and the level of financial sector development. They also indicated that the domestic saving rate in Developing Asia as a whole will remain roughly constant during the next two decades because the negative impact of population aging thereon will be roughly offset by the positive impact of higher income levels thereon.

In general, we can conclude from the previous literature that the determinants of saving performance are diverse. Most empirical studies emphasized the significant and negative influence of government savings on the saving rates, confirming the claim that government savings tend to crowd out private savings. Moreover, direct positive association between GDP growth rate, GDP per capita growth rate and private savings, indicates that these variables represent the most important determinants of private and public savings. Interest rate, inflation rate and terms of trade appear to have an ambiguous impact on saving levels. Moreover, demographic factors such as dependency ratio and urbanization rate seem to have a negative effect on private saving rates, however, the significance of these variables was mixed between studies.

However, taking into account the differences in economic, social, and demographic conditions among countries, we should not assume that factors, which successfully have explained saving performance in one country or in a group of countries, would be certainly appropriate or successful elsewhere. Some of these factors may be significant in one case, but not in others, and thus they should be carefully examined taking into consideration the characteristics of each case. Thus, we try in this study to examine macroeconomic factors that explain national saving behavior in Saudi Arabia, which may help policy makers to formulate policies that enhance saving ratios.

\section{III- Some Indicators of the Study Variables}

Saving rates in Saudi Arabia witnessed some fluctuation during the study period. The behavior of national savings as a percentage of GDP presented in table (1) and Fig. (1) shows a remarkable decrease trend during the period $(1980-1990)$ where this ratio decreases from about $57 \%$ to $13.5 \%$ with an average rate of $25.68 \%$. However, since the beginning of $1990 \mathrm{~s}$ until the end of the study period, this ratio witnessed an upward trend to reach about $42 \%$ on average during the last decade. In international perspective, Saudi Arabia have witnessed a high national saving rate since the last decade similar to those in some emerging countries such as China, Malaysia, Singapore, Thailand and India., and relatively higher than those rates of some developed countries (Table 2).

On the other hand, the growth rate of per capita income witnessed a sharp decline during the first half of 1980s to reach negative records in most years of this decade. This trend did not change dramatically during the $1990 \mathrm{~s}$ where the growth rate of per capita income was about $2 \%$ on average. However, this trend started to improve with the beginning of $2000 \mathrm{~s}$ with an average of $6.8 \%$ during this decade.

The public budget witnessed a deficit since the med of 1980s until the beginning of 2000s. The trend of the public deficit recorded an increasing trend as a percentage of GDP during the second half of 1980s; however, this ratio of deficit showed a decline after that. 
Since the beginning of 2000s, the public budget witnessed a surplus in most years until the end of the study period (2010).

With regard to foreign savings as represented by changes of foreign reserves, it was negative in most years through the period 1980-2000. However, this trend showed a remarkable increase during 2000s to reach, on average, about $10.87 \%$ of GDP. On the other hand, Inflation rate witnessed downturn trend during the first half of 1980s and recorded a negative value in some years, and continued to record a reasonable inflation rate until the beginning of 2000s which did not exceed 5\%. However, since 2001 and until 2010, inflation rate stated to record an increasing trend, which researched about $10 \%$ in 2008. (See table 1 and figure 1).

Table (1)

Descriptive Statistics of Variables Used in the Econometric Model.

\begin{tabular}{c|c|c|c|c|c|c|c}
\hline \hline Vtats. Var. & \multirow{2}{*}{ NSR } & BDR & FRR & GPCI & INF & MR & POPG \\
\hline \hline 1981 - 1990 & & & & & & & \\
- Mean & 25.68 & 7.84 & -0.20 & -2.09 & 0.27 & 38.12 & 5 \\
- Max & 56.96 & 25.3 & 23.04 & 39 & 4.4 & 53.98 & 5.06 \\
- Min & 13.49 & -20.3 & -11.73 & -20 & -3.16 & 17.27 & 4.91 \\
\hline 1991 - 2000 & & & & & & & \\
- Mean & 27.72 & 7.09 & 0.078 & 2 & 0.857 & 46.18 & 3.04 \\
- Max & 36.20 & 18.4 & 6.39 & 14 & 4.98 & 51.88 & 6.27 \\
- Min & 22.36 & -3.2 & -5.52 & -14 & -1.28 & 43.69 & 1.95 \\
\hline 2001- 2010 & & & & & & & \\
- Mean & 42.43 & -9.23 & 10.87 & 6.8 & 2.73 & 54.97 & 3.02 \\
- Max & 50.17 & 6.1 & 28.77 & 23 & 9.91 & 72.84 & 5.32 \\
- Min & 34.18 & -32.5 & -8.64 & -24 & -1.11 & 46.82 & 2.32 \\
\hline \hline
\end{tabular}

Source: Data calculated by the author depending on data from Saudi Arabian Monetary Agency

NSR: The ratio of national saving to GDP,

FRR: The ratio of changes of foreign reserves to GDP,

GPCI: The growth rate of per capita income,

BDR: The ratio of budget deficit to GDP,

MR: The ratio of broad money supply (M3) to GDP,

INF: The inflation rate,

POPG: Population growth.

Table (2)

Gross Domestic Saving Rates of GDP in Some Selected Countries in 2010

\begin{tabular}{c|c}
\hline \hline Country & Gross Domestic Saving Rate \\
\hline \hline China & 52 \\
Korea & 32 \\
Malaysia & 39 \\
Singapore & 52 \\
Thailand & 33 \\
India & 32 \\
Canada & 20 \\
Germany & 23 \\
Japan & 21 \\
Spain & 21 \\
U.K. & 13 \\
U.S. & 12 \\
\hline \hline
\end{tabular}

Sources: World Development Indicators, World Bank. 

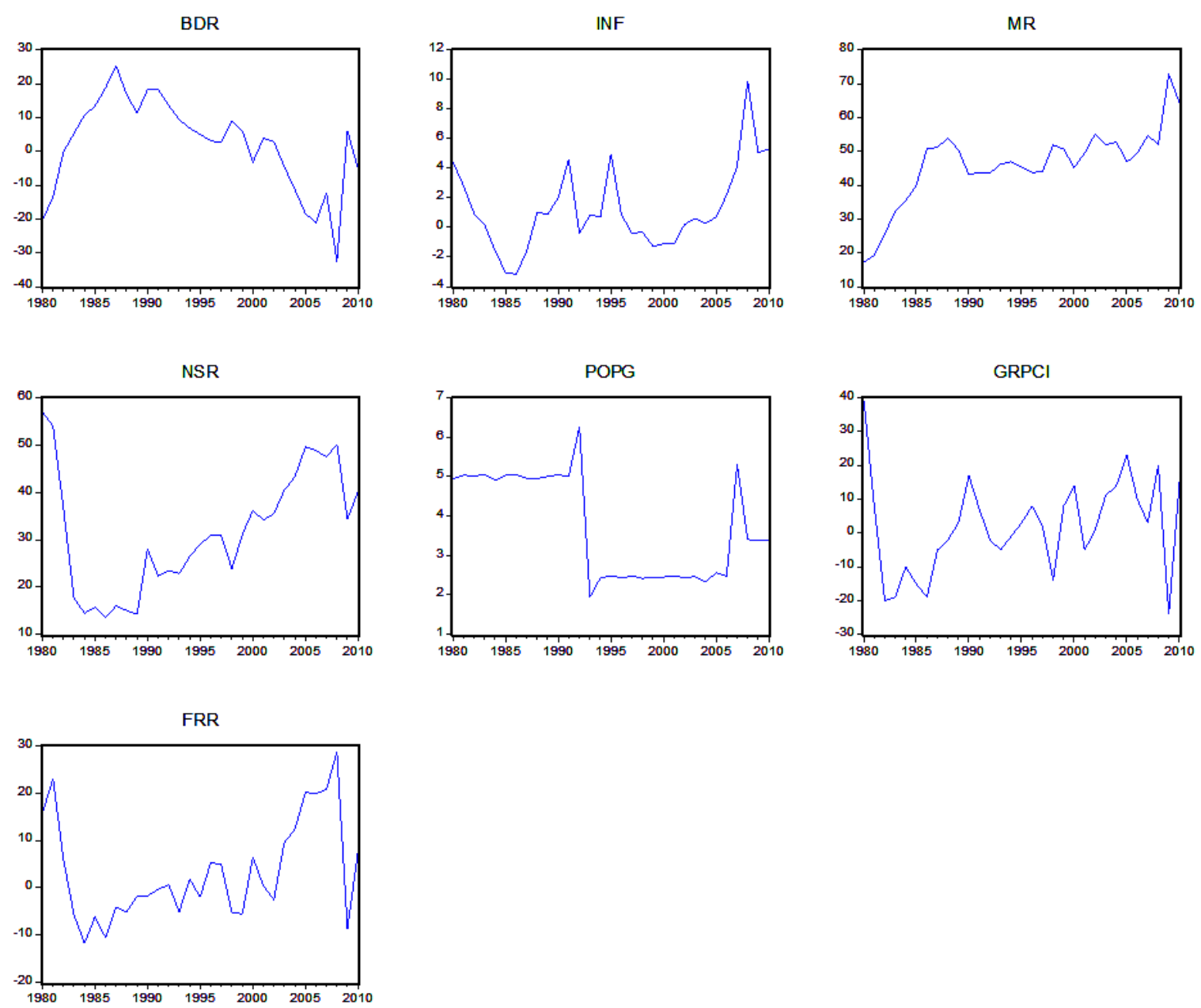

Source: Done by the researchers using eviews5 software

Fig. (1): Trends of Variables through the Period (1980 - 2010)

\section{The Empirical Model and Results}

The discussion of literature review suggests a number of factors, which might be important in determining domestic saving behavior in Saudi Arabia. This study tries to explain the behavior of national saving depending on macroeconomic variables covering the period 1980-2010. Data is based largely on Saudi Arabian Monetary Agency, which provides a long time series data of most variables used in the model. First, we outline the dependent variables used in our model, and then we outline the methodology adopted and the results.

So, the initial model can be represented as follow:

$$
N S R_{t}=\alpha_{0}+\alpha_{1} \mathrm{GPCI}_{t}+\alpha_{2} B D R_{t}+\alpha_{3} M R_{t}+\alpha_{4} I N F_{t}+\alpha_{5} F R R_{t}+\alpha_{6} P O P G_{t}+u_{t}
$$

The dependent variable is the ratio of national saving to GDP (NSR). National saving was calculated using the national accounting identity in an open economy (national savings = investment + net exports) 
The independent variables of macroeconomic determinnats of domestic savings can be defined in the following way ${ }^{(2)}$ :

GPCI- is the growth rate of per capita income,

BDR- is the budget deficit ratio to GDP. (Budget deficit is expressed in positive values so that an increase of budget deficit ratio is represented by the increase of the value of this ratio),

MR- is the ratio of broad money supply (M3) to GDP,

INF- is the inflation rate, measured as the growth rate of the index number of living costs as a proxy of macroeconomic stability,

FRR- is the change in foreign reserves to GDP [as a proxy of foreign savings],

POPG- is population growth rate.

Most macroeconomic time series exhibit substantial co-movement, and thus estimating the previous model using OLS frequently suffers from the problem of non-stationary regressors and spurious regressions, which do not reflect long-run relationship but common time trends (Engle and Granger, 1987). Therefore, in order to investigate the log-run effects of the model, we should first test whether the proposed variables in the model are stationary or not. This step is carried out using Augmented Dickey Fuller (ADF) test. ${ }^{(3)}$ The next step is to test for the presence of co-integration among the explanatory variables.

The procedure to test for stationary in the levels of variables starts with the most unrestricted model (a drift and time trend are included) as shown in equation below:

$$
X_{t}-X_{t-1}=\Delta X_{t}=\alpha+\beta T+\rho X_{t-1}+\gamma \Delta X_{t-1}+\varepsilon_{t}
$$

Where $X_{t}$ represents the variable of interest, $\mathrm{T}$ is a time trend. The null hypothesis that $X_{t}$ is non-stationary ( $\beta=0$, and $\rho=1$ ) is rejected if the coefficient on $X_{t-1}$ is significantly negative. For the ADF test, one must specify the number of lagged first difference terms to add in the test regression. In this study, the proper lags are specified according to Schwarz Information Criterion (SIC).

There are two other forms of the ADF test:

a- Models with intercept, but without trend;

b- Models without both intercept and trend.

(2) We don't include the interest rate as one of the explanatory variables in the model due to the privacy of Saudi society, where the Saudi society looks to the interest rate as a usurious interest rate and then it does not represent one of the determinants of savings in the Saudi society.

(3) For more details, see: Dickey, D. and Fuller, W., "The likelihood ratio statistics for autoregressive time series with a unit root”, Econometrica, Vol. 49, 1981: pp. 1052-72. 
المجلة العببة للإدارة، مج؟؟، ع1- يونيو (حزيران)/ع-ديسمبر (كانون أول) ؟؟؟؟

The three forms of the ADF test are conducted in this study to check for a unit root for all variables in both levels and first differences. The results of these tests are presented in Table (3), which reveal that the hypothesis of a unit root cannot be rejected in levels for variables NSR, BDR, MR, INF, and POPG, whereas FRR and GPCI series are stationary in a variable level. However, the hypothesis of a unit root is rejected in first differences for variables NSR, BDR, MR, and INF.

Table (3)

Augmented Dickey-fuller Test for Unit Root Null Hypothesis: The Series Has a Unit Root (Non-stationary)

\begin{tabular}{l|c|c|c|c|c|c}
\hline \hline \multirow{3}{*}{ Variable } & \multicolumn{6}{|c}{ ADF Statistics } \\
\cline { 2 - 7 } & \multicolumn{5}{|c|}{ Variable level } & \multicolumn{3}{c}{ 1st Difference } \\
\cline { 2 - 7 } & Intercept & $\begin{array}{c}\text { Intercept } \\
\text { \& Trend }\end{array}$ & None & Intercept & $\begin{array}{c}\text { Intercept } \\
\text { \& Trend }\end{array}$ & None \\
\hline \hline NSR & -2.182 & $-3.751^{* *}$ & -1.197 & $-4.432^{* * *}$ & $-4.710^{* * *}$ & $-4.505^{* * *}$ \\
\hline BDR & -1.805 & $-3.576^{* *}$ & $-1.699^{*}$ & $-7.691^{* * *}$ & $-7.798^{* * *}$ & $-7.814^{* * *}$ \\
\hline MR & -2.337 & -2.866 & -1.191 & $-6.215^{* * *}$ & $-6.148^{* * * *}$ & $-5.799^{* * *}$ \\
\hline FRR & $-2.971 * *$ & $-3.532^{*}$ & $-2.909^{* * *}$ & & & \\
\hline INF & -2.353 & -2.961 & $-2.148^{* *}$ & $-6.439^{* * *}$ & $-6.534^{* * *}$ & $-6.550^{* * *}$ \\
\hline GPCI & $-4.798^{* * *}$ & $-5.681^{* * *}$ & $-4.887 * * *$ & & & \\
\hline POPG & -2.364 & -2.927 & -0.927 & $-8.089^{* * *}$ & $-7.983^{* * *}$ & $-8.198^{* * *}$ \\
\hline \hline
\end{tabular}

Calculated by the researchers using Eviews5 software

$*, * *, * * *$ denote rejection at $10 \%, 5 \%$ and $1 \%$ respectively

(Note: The critical values of the table are not from normal t-tables but calculated by Dickey and Fuller)

As not all the variables are integrated of the same order, we can't apply the cointegration test and thus we can't apply vector error correction model (VECM). However, we can apply unrestricted vector autoregressive (VAR) model for our data as it does not require the series to be integrated of the same order. This model provides a multivariate framework where changes in a particular variable are related to changes in its own lags and to changes in other variables. To estimate a VAR-model properly, we need stationary data. Therefore, we estimated the VAR model with first difference of all variables. First, we have selected appropriate lag length on the basis of Schwarz information criterion by using VAR test. The appropriate selected lag length is 2 . Therefore the using VAR model is:

$$
\begin{aligned}
\Delta N S R_{t} & =\alpha_{0}+\alpha_{1} \Delta N S R_{t-1}+\alpha_{2} \Delta N S R_{t-2}+\alpha_{3} \Delta M R_{t-1}+\alpha_{4} \Delta M R_{t-2}+\alpha_{5} \Delta I N F_{t-1} \\
& +\alpha_{6} \Delta I N F_{t-2}+\alpha_{7} \Delta B D R_{t-1}+\alpha_{8} \Delta B D R_{t-2}+\alpha_{9} \Delta P O P G_{t-1}+\alpha_{10} \Delta P O P G_{t-1} \\
& +\alpha_{11} \Delta G P C I_{t-1}+\alpha_{12} \Delta G P C I_{t-2}+\alpha_{13} \Delta F R R_{t-1}+\alpha_{14} \Delta F R R_{t-2}+u_{t}
\end{aligned}
$$

Table ( 4 ) reports the final results of the estimated VAR model, together with a set of commonly used diagnostic statistics. First, fitting of the model seems to be statistically acceptable. $\mathrm{R}^{2}$ is about $64.1 \%$, and $\mathrm{F}$-value is about 3.57 , which is significant at $1 \%$. 
Table (4)

Results of the Estimated VAR Model

DNSR: dependent variable

R-squared

0.641

Log likelihood

$-407.717$

7.293

F-Statistic

3.57

Schwarz information criterion (SIC)

P-value

0.01

Included observations: 28 after adjustments

\begin{tabular}{l|c|c|c|c}
\hline \hline \multicolumn{1}{c|}{ Variable } & Coefficient & Std. Error & T-Statistic & P-value \\
\hline \hline DNSR(-1) & -0.014 & 0.269 & -0.05 & 0.959 \\
\hline DNSR(-2) & 0.655 & 0.269 & 2.43 & 0.030 \\
\hline DMR(-1) & 0.894 & 0.312 & 2.86 & 0.013 \\
\hline DMR(-2) & 0.084 & 0.356 & 0.24 & 0.817 \\
\hline DINF(-1) & -0.423 & 0.463 & -0.91 & 0.377 \\
\hline DINF(-2) & -0.680 & 0.437 & -1.56 & 0.144 \\
\hline DBDR(-1) & -0.483 & 0.196 & -2.47 & 0.028 \\
\hline DBDR(-2) & -0.867 & 0.195 & -4.45 & 0.001 \\
\hline DPOPG(-1) & 2.721 & 1.053 & 2.58 & 0.023 \\
\hline DPOPG(-2) & 0.605 & 0.935 & 0.65 & 0.529 \\
\hline DGRPCI(-1) & 0.360 & 0.195 & 1.84 & 0.089 \\
\hline DGRPCI(-2) & 0.049 & 0.089 & 0.55 & 0.591 \\
\hline DFRR(-1) & -0.442 & 0.268 & -1.65 & 0.123 \\
\hline DFRR(-2) & -0.773 & 0.224 & -3.45 & 0.004 \\
\hline Constant & -0.909 & 0.859 & -1.06 & 0.309 \\
\hline \hline
\end{tabular}

Note: Letter D before each variable refers to the first difference of the variable, and the number between brackets after the variable refers to the number of lags.

The estimated paramaters of the explainatory variables point out that the growth rate of per capita income has a positive effect on national savings ratio as expected and statistically significant at 10 percent level. A one percent increase in the growth rate of per capita income in year $(t)$ seems to bring about 0.36 percent increase in national saving rate in year $(t+1)$. This provides support for the argument that the level of income is a determinant of the capacity to save. If the growth rate in GDP were higher than the growth rate in population, this would increase the level of per capita GDP, which in turn would increase the level of private savings.

With regard to population growth, our results indicate that there is a positive relationship between population growth and national saving rate. The first lag of population growth ratio seems to have a significant positive effect on national saving ratio at $5 \%$ level of significance. This result is consistent with the result of (Al-Mohaimeed 2000) in which birth rates have positive impact on domestic savings. As Al-Mohaimeed indicated, this is consistent with the special characteristic of Saudi society, in which children keep living with their parents for long period and contribute, therefore, to family income.

On the other hand, macroeconomic uncertainty as measured by the inflation rate (INF) seems to be negatively influence saving rate (the parameters of the first and second lags are negative), however, it is not statistically significant. The financial depths as captured by DMR has a positive and significantly effect on national savings especially the first lag which is significant at $5 \%$ level of significance. This implies that an increase in financial depth is likely to have positive effect on 
national saving ratio especially in a country such as Saudi Arabia, which witnesses a high degree of development of the financial system especially in recent years.

Add to that, foreign reserves ratio as an indicator of foreign savings recorded a negative and statistically significant effect on national savings. The results indicate that 1 percent increase in foreign reserves ratio in year $(t)$ leads to 0.773 a percent point decrease in national saving ratio in year $(\mathrm{t}+2)$. This implies that an increase in foreign savings is met by a partial decearse in national savings, which indicates that foreign saving may tend to act as a substitute to national savings.

The conventional analysis of sustained budget deficits indicates that an increase in the budget deficit reduces national saving unless it is fully offset by an increase in private saving. Our results confirm this viewpoint, where the budget deficit ratio (both the first and second lag) has a negative and statistically significant effect on the national saving ratio. The coefficient of the first and second lags of budget deficit ratio indicate that an increasing in this ratio by 1 percent leads to a decrease in national saving ratio by about 0.483 and 0.867 percentage points in years $(t+1)$ and $(t+2)$ respectively. This result does not support the Ricardian hypothesis, which implies that the reduction in government savings (more budget deficit) is offset totally by an increase in private savings and therefore this will not affect the national savings. The explanation of that result is the Saudi Arabia doesn't depend on taxes to cover its budget deficit, and therefore the Ricardian hypothesis is not applicable in Saudi Arabia due to the limited use of taxes as a tool of fiscal policy.

Finally, the savings rate of the second lag seems to have a positive and significant effect on today's savings rates. The coefficient is about 0.655 indicating that savings rates clarify a certain degree of persistence.

When we compare our results with results of Al-Mohaimeed (2000), we see that the effects of population growth, budget deficit and income on national savings are consistent with the results of Al-Mohaimeed (2000). Although foreign saving seems to be a substitute to national saving in our results, it appears to be a complementary (but not significant) in the results of Al-Mohaimeed (2000). Moreover, our results refer to the important role of financial depth on national savings which is not covered by Al-Mohaimeed (2000).

\section{V- Conclusion and Policy Implication}

This paper has analyzed the determinants of national savings in Saudi Arabia during the period 1980-2010. The unit root test was used to test the stationary of all time series, and the resuls of ADF test indicated that some variables are sationary at first difference, and others are sationary at variable level, thus unrestricted VAR model is the proper model in this case. The results of the estimated VAR model provide evidence that the growth rate of per capita income is found to have positive influence on national savings. Second, population growth seems a positive relationship effect on national saving rate. This result is consistent with the result of (Al-Mohaimeed 2000) in which birth rates have positive impact on domestic savings.

On the other hand, inflation rate seems to have insignificant effect on national saving ratio, which indicates that economic uncertainty does not have influence on Saudi Arabia national savings during the period study. The financial depth as captured by DMR has a positive and significantly effect on national savings. This implies that an increase in financial 
depth is likely to have positive effect on national saving ratio especially in a country such as Saudi Arabia, which witnesses a high degree of development of the financial system especially in recent years. Add to that, foreign reserves ratio as an indicator of foreign savings recorded a negative and statistically significant effect on national savings, which implies that foreign saving may tend to act as a substitute to national savings.

With regard to the effect of budget deficits, results of our study confirm that budget deficit ratio (both the first and second lag) has a negative and statistically significant effect on the national saving ratio, which does not support the Ricardian hypothesis due to the limited use of taxes as a tool of fiscal policy in Saudi Arabia. Finally, the savings rate of the second lag has a positive and significant effect on today's savings rates, indicating that savings rates clarify a certain degree of persistence.

The main policy implication of our study is related to the negative effect of government deficit on national savings, which suggests that government should use fiscal policy (especially government expenditure) to reduce budget deficit and thus increase national savings, and restructure government expenditure in the way that can boost private savings and thus offset the negative effect on national savings. The government should maintain a balanced budget, and if there is a deficit in the budget due to an emergency reduction in overall revenues, it is preferred to treat this by reducing non-investment spending to avoid the negative impact on the private saving rate. On the other hand, as the Saudi economy depends on petroleum revenues as the main source of public revenues, the government should work to diversify their revenue to avoid fluctuation of petroleum revenues and maintain a balanced budget.

Another implication policy is about the effect of financial depth on national savings. Our results suggest that deeper financial system will tend to have higher national savings. Therefore, developing financial system in Saudi Arabia may contribute deeply in mobilizing private savings and thus increase the level of national savings. 


\section{References}

- Athukorala, P. and K. Senm. (2004). "The Determinants of Private Saving in India". World Development. Vol. 32, Issue (3), 491-503.

- Al-Mohaimeed, A. (2000). "Saving in Saudi Arabia: An Empirical Investigation". Economic Studies, Vol. 2, No. (4), $11-35$.

- Callen, T. and C. Thimann. (1997). "Empirical Determinants of Household Savings: Evidence From OECD Countries ". IMF Working Paper. WP/97/181.

- Cardenas, M. and A. Escobar. (1998). "Saving Determinants in Colombia: 1925-1994". Journal of Development Economics. Vol. 57, Issue (1), 5-44.

- Dayal-Ghulati, A. and C.Thimann. (1997). "Saving in Southeast Asia and Latin America Compared: Searching For Policy Lessons". IMF Working Paper. WP/97/110.

- Dickey, D. and W. Fuller. (1981). "The Likelihood Ratio Statistics for Autoregressive Time Series with a Unit Root", Econometrica. Vol. 49, 1052-72.

- Edwards, S. (1996). "Why Are Latin America's Savings Rates So Low? An International Comparative Analysis", Journal of Development Economics. Vol. 51, Issue (1), 5 - 44.

- Engle, R. and c. Granger. (1987). "Cointegration and Error Correction: Representation, Estimation and Testing". Econometrica. Vol. 55, 251-76.

- Gough, J. (2011). "Determinants of the U.S. Household Saving Rate: An Econometric Analysis". Political Economy, Vol. 20, 28-44.

- Hallaq, S. (2003). "Determinants of Private Savings: The Case of Jordan (1976-2000)", Journal of King Saud University “Administrative Sciences”, Vol. 15, Issue (2), 83-94.

- Horioka, A. and A. Terada-Hagiwara. (2012). "The Determinants and Long-term Projections of Saving Rates in Developing Asia". Japan and the World Economy, Vol. 24, 128-137.

- Hussain, M. and O. Brookins. (2001). "On the Determinant of National Savings: An Extreme-bounds Analysis", Review of World Economics. Vol. 137, Issue (1), 150-174.

- Hussein, K. and A. Thirlwall. (1999). "Explaining Differences in the Domestic Savings Ratio Across Countries: A Panel Data Study". Journal of Development Studies. Vol. 36, $31-52$.

- Jappelli, T. (2005). "The Life-cycle Hypothesis, Fiscal Policy, and Social Security". Working Paper No. 140, Centre for Studies in Economics and Finance, University of Salerno, Italy. May.

- Khan, A.; L. Hasan and A. Malik. (1994). "Determinants of National Savings Rate in Pakistan". Economia Internazionale. Vol. 47, Issue (4), 365-82.

- Keho, Y. (2011). "Long-run Determinants of Savings Rates in WAEMU Countries: An Empirical Assessment From ARDL Bounds Testing Approach". South African Journal of Economics, Vol. 79, Issue (3), 312-329.

- Kim, M. (2010). "The Determinants of Personal Saving in the U.S."Journal of Applied Business Research, Vol. 26, No. (5), 35-44. 
- Loayza, N.; K. Schmidt-Hebbel, and L. Servén. (2000). "Saving in Developing Countries: An Overview". World Bank Economic Review. Vol. 14, Issue (3), 393-414.

- Masson, R.; T. Bayoumi, and H. Samiei. (1998). "International Evidence on the Determinants of Private Savings", The World Bank Economic Review. Vol. 12, Issue (3), 483-501.

- Metin_Özcan, K. and Y. Özcan. (2005). "Determinants of Private Savings in the Middle East and North Africa", In: Money and Finance in the Middle East: Missed Opportunities or Future Prospects?, S. Naime and N. Colton (eds.). Research in Middle East Economics, Amsterdam and Oxford: Elsevier, Vol. 6, 95-117.

- Modigliani, F. (1986). "Life Cycle, Individual Thrift, and the Wealth of Nations". American Economic Review. Vol. 76, 297-313.

- Narayan, P. and S. Al-Siyabi. "An Empirical Investigation of the Determinants of Oman's National Savings", Economics Bulletin. Vol. 3, 1-7.

- Odhiambo, N. (2008). "Financial Depth, Savings and Economic Growth in Kenya: A Dynamic Causal Linkage". Economic Modelling . Vol. 25, 704-713.

- Odhiambo, N. (2009). "Savings and Economic Growth in South Africa: A Multivariate Causality Test", Journal of Policy Modeling, Vol. 31, 708-718.

- Özcan, K.; A. Gunay and S. Ertac. (2003). "Determinants of Private Savings Behavior in Turkey". Applied Economics. Vol. 25, Issue (12), 1405-1416.

- Sarantis, N. and C. Stewart. (2001). Savings Behavior in OECD Countries: Evidence Form Panel Cointegration Tests. The Manchester School. Vol. 69, 22-41.

- Saudi Arabian Monetary Agency. (2011). Anual Report. (47). 